\title{
Defense Reform of the Albanian Armed Forces: Democratization and Transformation
}

\author{
Enika Abazi *
}

The reform of the Albanian Armed Forces began in 1991, together with the transformation of Albanian society from a centralized planed economy to a market-oriented one with respect for rule of law and democratic values. The reform of the armed forces is a complex process that is complicated even more by the ways that national interests are defined in the post-Cold War era since, in addition to the multi-polar environment, nations are facing an advanced stage of the globalization of relationships among states and societies. At the present time, as Marco Carnovale states, "vital security interests are no longer national interests, and national security interests are no longer vital.", Vital national interests are challenged by a wide range of problems that go beyond the traditional military concerns that have almost become anachronistic in the face of terrorism, migration, civil unrest, resurgent nationalistic splits, and further escalations of tensions across borders, including economic and environmental problems.

Facing these new challenges, the armed forces need to be reformed in order to enable them to meet the requirements of security needs at national, regional, and international level. The process of reform should imply two dynamics. First, reform should aim at the creation of professional and efficient armed forces that are able to satisfy all kinds of national security needs. Second, the reform process should complete the democratic control of the armed forces and the military establishment. This process requires the subordination of military forces and structures to civilian control, a process necessary to prevent military abuse of power. This paper will attempt to cover in a synthetic way both dimensions of the military reform that is oriented toward making the Albanian armed forces capable of operating within the framework of the North Atlantic Alliance, as well as able to meet all challenges to Albania's national security.

In recent years there have been many works published on NATO enlargement and the candidate states for prospective membership. However, there are very few academic works that attempt to tackle Albania's membership in NATO, especially as it

* Enika Abazi is the Director of European Programs, Albanian Institute of International Studies. At the same time she is a Ph.D. Candidate in the Department of International Relations at Bilkent University in Ankara, Turkey.

1 Marco Carnovale, "Vital and National Security Interests after the End of the Cold War," in European Security and International Institutions, ed. Marco Carnovale (New York: St. Martin's Press, 1991), 1. 
relates to the defense reform of the Albanian armed forces. ${ }^{2}$ This paper will attempt to fill the gap in the literature by presenting a broad picture of the democratization and transformation of the Albanian armed forces that has been effected by a combination of domestic, regional, and international dynamics. It is my sincere hope that this article will give the subject at least some of the attention it properly deserves.

\section{Democratization of the Albanian Armed Forces}

\section{Tradition and Particularities}

In order to better understand the process of democratization of the armed forces in Albania, it is important to mention two of the main particularities of the Albanian military sector. The specification of these particularities is important for tailoring the reform to unique steps that are needed to bring the Albanian army up to the required levels of modernization, professionalization, and democratization. Two are the most idiosyncratic features that can be said to define the state of civil-military relations in Albania. First, historically there have been no tendencies in the Albanian army to seize control over politics and civic affairs. This is an attribute of the Albanian army that find its explanations in the national tradition rather than in the establishment and functioning of democratic institutions, since Albania - as is the case in most of the states of the region-is lacking in democratic experience and tradition. Albanians have had a reputation for martial excellence for nearly 2000 years. Nevertheless, they have rarely fought in a politically organized manner. Therefore, despite Albania's military heritage, the military establishment there cannot be considered to be an important component of politics and civic affairs. Neither has the military shown the propensity to intervene in domestic politics.

Second, while there is little evidence of the tendency of military structures to intervene in the civic affairs, the opposite tendency is discernible. The (mis)use of the military by civilians is a dimension of civil-military relations in Albania, and herein lies the problem. In practice, politicized and partisan reforms have negatively influenced the process of democratization and professionalization of the armed forces and its establishment. The military has often been the target of political purges in the event of drastic changes in the governance of the country. ${ }^{3}$

2 Under the initiative of DCAF, a self-assessment study was undertaken on the governance and reform of the Albanian armed forces. Jan A. Trapans and Philipp H. Fluri edited the study in a publication entitled Defence and Security Sector Governance and Reform in South Eastern Europe: Insights and Perspectives. A Self-Assessment Study (Geneva: DCAF, 2003). Another interesting paper on the issues of military reform is offered by Ryan C. Hendrickson and Jonathan Campbell, in "NATO Expansion after Prague: Albania's Response to the 'Open-Door' Policy," The Review of International Affairs (forthcoming, 2004).

3 See more on this topic in Elmas Leci's Eleminimi i Lidershipit Politic (The Elemination of the Political Leadership) (Tirana: Instituti i Sigurimit dhe Mbrojties, 2002), 463-70; and Besnik Mustafaj, Albanian Human Development Report 1998 (Tirana: UNDP, 1998), 78. 
There are cases when civilians have used the military in Albania in order to achieve their political goals. The crisis of $1997^{4}$ provided some interesting examples in support of this argument, although this tendency should not be considered as the only explanation for what happened. It is worth mentioning that the disintegration of the entire Albanian military establishment and the dispersal of most of its military arsenal created a great challenge for the continuation of defense reforms. The events of 1997 are very complex, and as such understanding them requires historical distance, in order that they can be fully analyzed and considered. However, the crisis of 1997 will not be discussed further here, since it goes beyond the scope of this paper.

\section{Three Dimensions of the Democratization of the Albanian Armed Forces}

The process of the democratization of the army is a complex and long one. The process can be better understood if divided into its three components: procedures, legal aspects, and politics. This division is to render the issues more easily understood, since they are more readily grasped in stages rather than in the full idiosyncrasy of the reform process. The actions undertaken in each category are complementary to each other, and each one represents a critical element of the process of democratizing the Albanian armed forces.

Under the procedural framework of the reforms are considered all measures, procedures, and mechanisms necessary to ensure the smooth functioning of the military establishment, the exercise of civilian control and participation, and the provision of information to the public. The reform of the procedural framework aimed to improve the professionalism of the army in terms of its efficiency, efficacy, and accountability. Under this framework, measures were adopted to introduce the military ranks that were abolished during the Communist era. This measure is considered an important step towards the creation of a professional and sustainable army.

Another important dimension of these reforms is the undertaking of measures and instruments that are considered important for increasing the transparency and accountability of decision-making in the security and military sector. For example, as a result of these reforms, political documents on security and defense issues are generally not classified as state secrets; as such, de jure, the organizations of civil society have access to those documents, and can exercise control at the same time. Continuing on the same line, the Ministry of Defense has considered the publication of "Defense White Papers" intended to inform the civil sphere about the activities of the different structures of military establishment. However, this decision has still not been made manifest

41997 was a momentous year for Albania. A general violent outburst spread all over the country due to the frustration caused by the loss of life savings by hundred of thousands of Albanians in a large number of "pyramid" investment schemes. The event was followed by a total disintegration of the nation's military structures and capabilities. As a result, conscripts abandoned military units and their officers, military installations became prey to criminal elements, and arms and ammunition were stolen. This situation led to new elections and the establishment of a new socialist government. 
in any actual publications, and in practice there are several technical difficulties that prevent civilian control over the military from taking place.

The other direction of these reforms is legal. A packet of laws has been developed to support the legal basis of strengthening civilian control over the armed forces. The constitution of 1998 sets out the basic dispositions that regulate civilian-military relations and responsibilities in the defense sector. Under the constitution, the Parliament is the most important instrument for the control of the entire military establishment and its structures. In the case of threats or international requirements for collective action, it is the Parliament that confirms the decision of the President on the declaration of the state of war and calls for the mobilization of reservists. Still, the Parliament is not involved in the process of appointments within the army.

The powers of the President are reduced in the new constitution. Still, the President is the commander in chief of the armed forces. In peacetime, the President exercises his authority over the armed forces through the Prime Minister and the Minister of Defense. In times of war, he enjoys complete command authority over the armed forces. The National Security Council is an advisory body to the President of the Republic, but it does not have the power to restrict the President in his decisions. The advisory concept is new in comparison with the previous constitutional framework, which assigned decision-making duties to the National Security Council. However, the role of the Council during peacetime is not very clear. The council is supposed to offer advice on military matters to a President that has a rather passive role and does not exercise military authority in peacetime.

The Prime Minister and the Council of Ministers prepare and propose to the Parliament and the President the main documents on defense policy. The Council of Ministers proposes the whole budget for the military establishment, and also is responsible for putting forth extraordinary measures over part or all of Albanian territory. The Prime Minister in particular proposes the nomination or the removal from office of the Chief of Staff, appoints heads of departments in the Ministry of Defense, and also appoints the General Staff, with the exception of the generals. The Minister of Defense by constitutional requirement is a civilian, and represents the highest official during peacetime of all military and civilian personnel of the armed forces. The Minister is responsible to the Parliament, the President, and the Prime Minister for implementing defense policies. The Minister of Defense has the authority to propose defense policies, budgets, military appointments (except for the rank of general), and military attachés. In law there is a gray area regarding the role of the Minister of Defense in wartime, particularly concerning appointments, which is an issue that needs clarification.

The Chief of the General Staff is elected for a three-year period with an extension option. Based upon a proposal by the Prime Minister, the President appoints the Chief of the General Staff, who is required to have the rank of General and the necessary military experience. The Chief of the General Staff is responsible to the President, Prime Minister, and the Minister of Defense, which assures the neutrality of the post. 
In times of war, the Chief of General Staff can be nominated Commander of the Armed Forces. ${ }^{5}$

It is important to dwell a little bit longer on the oversight role of the Parliament as the institution that not only performs the democratic control functions but also at the same time assures transparency and accountability in the process of governance in Albania, including the military. Parliament has a say in the policy-making process that is made possible through the functioning of the Standing Parliamentary Committee. This committee has different sub-committees that deal with particular issues, including the armed forces and the intelligence service. In addition to this committee, ad hoc and investigative committees have been created for specific functions, aiming to enhance the oversight role of the Parliament. The Parliamentary Defense Committee is the main instrument of Parliament's democratic control over the armed forces; at the same time, it helps ensure the transparency and the accountability of the process. The Defense Committee is an instrument of the parliament that oversees the implementation of the defense budget, checks and assesses the efficacy of existing laws, and recommends appropriate amendments in cases where they are required. The committee can ask for explanations from the Minister of Defense of various issues, and can accordingly suggest measures to be taken by the Parliament or the Council of Ministers.

Although the Parliamentary Defense Committee was envisioned as being an important instrument of control over the armed forces, there are in practice many factors that handicap its proper functioning. Among others, it can be mentioned that there is a lack of the necessary expertise and information to enable the work of the committee. For example, there is only one adviser providing expert support to the committee; the bulk of information provided to the committee comes from the government and military establishment, since alternative sources are missing. These deficiencies in providing the right information are aggravated by the very nature of the sector, which is often covered by secret and classified status. Furthermore, there is little interest demonstrated by the committee in defense issues, and as such the military budget normally is approved after three meetings, while on average two weeks are required for the approval of other budgets. There is a lack of debate in general, and defense issues are not high on the agenda of the NGOs. In addition, the measures that were supposed to be taken by the Ministry of Defense to increase transparency, such as the publication of periodic reports such as the "White Papers," have yet to materialize.

Political will is another important dimension of the reform of the armed forces. In general, the political parties define strategies and policies for reform and offer the political will to fulfill them. There are no major constraints coming from political parties on either the content or direction of defense reform. Still, the partisan nature of the

See more on the issue of constitution in Mentor Nazarko, "The Relationship between the Armed Forces and the New Institutions in Albania - A Model in the Making of Civilian and Democratic Control," in Defence and Security Sector Governance and Reform in South Eastern Europe: Insights and Perspectives. A Self-Assessment Study, eds. Jan A. Trapans and Philipp H. Fluri (Geneva: DCAF, 2003). 
debates in the Parliament can be observed even on security and defense issues, and this is having an impact on the reforms. More than in the parliamentary debates, the politicization of the reform process can be observed at the level of implementation. Political cronyism can be observed in the downsizing of the army, the upgrading of ranks, and the like. These political mockeries are blemishes on the successful accomplishment of reforms in the military sector.

\section{Transformation of the Albanian Armed Forces}

\section{NATO and the Transformation of the Albanian Armed Forces}

Defense reform of the Albanian armed forces requires the transformation of the nation's military capabilities, including personnel, equipment, and infrastructure, making them capable of meeting contemporary challenges. The developments in the transformation of the armed forces cannot be understood without considering the crucial role of NATO. The presence of NATO has provided much-needed orientation and a road map to follow, together with the financial aid that is indispensable in order for Albania to reach the necessary standards for joining the North Atlantic Alliance. Albania was among the first countries to join the North Atlantic Cooperation Council (NACC) in 1992 and the Partnership for Peace (PfP) in $1994 .^{6}$ These steps are considered important moves towards integration into the new Euro-Atlantic security architecture. PfP provides the essential assistance that serves to strengthen Albanian security, and also contributes to the strengthening of security and stability in the region, by enhancing confidence- and security-building measures among the Balkan countries by involving them in common exercises, exchanges of information, and meetings of the military staff and personnel at every level.

After the 1997 crisis that saw the dismantling of the Albanian armed forces, the PfP took the main role in developing a program of assistance to rebuild the armed forces through the Individual Partnership Program. This program had two pillars. The first pillar involved NATO as an organization in the provision of assistance. Another aim of the first pillar was to keep Albania tied to the main PfP activities within the framework of the Partnership Work Program. The assistance was concentrated in three areas:

- The development of the national defense concept and its legal framework, providing for democratic control of armed forces and civil-military relations;

- The structural reorganization and adjustment of military command and the armed forces, increasing their operational abilities and efficiency by developing an essential Command, Control, Communication, and Information (C3I) system;

- The resolution of technical issues related to the storage and safety of munitions and armaments.

6 Jane's Defence Weekly Interview 24:11 (16 September 1995). 
The second pillar aimed at channeling bilateral assistance from allies and Partner countries. The scope of this pillar was to assess Albania's necessities and priorities, and coordinate bilateral actions, avoiding overlaps. For this purpose a special forum of coordination named the Clearing House on Albania (CHA) was created, and a NATO office was established in Tirana, the only one in the Partner countries. ${ }^{7}$ Following these lines of cooperation, a new Individual Partnership for Peace program was signed between Albania and NATO for the year 1999. The program aims to strengthen the Albanian army and Albania's cooperation with NATO as an organization, as well as with its members and partners.

Preparing seriously for membership in NATO, the National Membership Action Plan (MAP) was issued by the Albanian Ministry of Defense in October 2001. ${ }^{8}$ The overall objectives of MAP cover a large spectrum and aim at the transformation of Albanian society, with a goal of enabling it to handle by itself all internal and external challenges to its security. The MAP objectives aim at:

- Continuation of reforms that would enhance the development of a market economy and rule of law, while fighting against corruption;

- Improving respect for human and minority rights, while supporting efforts for strengthening democratic institutions and increasing the efficiency of governance;

- Strengthening of civilian control over military structures and command while continuing the military reforms that aim at the harmonization of legislation with that of the North Atlantic Alliance;

- Increasing compliance and participation in international efforts to fight terrorism and organized crime in relation to the participation of Albania in the antiterrorist coalition of states.

In April of 2000, Albania accepted a very demanding Partnership Goal package, comprising fifty-three Partnership goals, of which thirty-one are MAP-related. This package aims primarily at improving the interoperability of the Albanian armed forces. This effort includes the continuation of involvement in the Planning and Review Process (PARP) as a central element of PfP that aims at restructuring the Albanian armed forces so that they will be more interoperable with other Alliance forces. This ambitious reform amounts to a comprehensive transformation of the Albanian armed forces. Its implementation is supposed to be part of the new Albanian Armed Forces Structure and Implementation Plans during the period 2002-2010. ${ }^{9}$

Under the framework of the Planning and Review Process (PARP) that is a central element of PfP, important steps are being taken toward restructuring and harmonizing Albanian military structures and capabilities in conformity with NATO standards; put-

7 On the assistance program after the crisis of 1997 see, G. Katsirdakis, "Albania: A Case Study in the Practical Implementation of Partnership for Peace," NATO Review 46: 2 (Summer 1998): 22-26.

8 Action Plan for Membership of Republic of Albania in NATO.

9 Ibid. 
ting decision-making structures and procedures under civilian control and compiling the necessary legal framework; and training and exercising military units in peacekeeping, humanitarian, and search and rescue missions. Under the same framework, a large number of joint exercises have been held between NATO and Albanian military forces. $^{10}$

\section{The Transformation Process}

The transformation of the Albanian armed forces follows NATO's guidelines for membership, which require increasing the "interoperability"11 and "deployability and usability" 12 of armed forces together with training military personnel to be able to fulfill these objectives. Within the framework of increasing the "interoperability" of the Albanian armed forces, measures are being taken to restructure, relocate, and downsize the peacetime active armed forces based on the reassessment of security needs defined as a function of a geo-strategic environment evaluation and the capabilities of the country. The size of the Albanian armed forces is supposed to be reduced to approximately 16,500 troops, instead of 31,000 of today. ${ }^{13}$ This figure incorporates the military staff of the Ministry of Defense; the General Staff; ground, navy, and air forces; the Doctrine and Training Center' and Logistics Command. The reformation of all these structures is being carried out according to NATO structural standards.

Ground forces are the largest formation of the Albanian Land Forces. It is foreseen that in the future the ground forces would be composed of professionals rather than conscripts, as is the case today. A rapid reaction mechanized brigade, with a battalion of the "task force" type, one commando regiment, and one sapper brigade are being created within the framework of the ground forces to perform advanced military ac-

10 See A. Copani, “The New Dimensions of Albania's Security Posture," NATO Review 44:2 (March 1996).

11 The "interoperability" of armed forces requires the development of additional resources for a particular unit within the Albanian military that could perform more advanced military activities for NATO. "Interoperability" as a concept was introduced and defined in the document issued by NATO: Study on NATO Enlargement (1995), available at: www.nato.int/ docu/basictxt/enl-9502.htm; and Final Communiqué, Press Release (2003) 148, "Meeting of the North Atlantic Council in Defense Ministers Session held in Brussels on Monday, 1 December 2002," available at: http://www.nato.int/docu/pr/2003/ p.03-148e.htm.

12 The "deployability and usability" of armed forces requires the rapid deployment of military and weaponry and its success. This recently introduced concept requires both the improvement of lift capabilities, in order to deploy and sustain the military in coping with diversified (in nature and geographic location) challenges and to train the military to be able to operate in all situations. The concept was introduced during the Prague Summit in November 2002 and restated at NATO's Defense Ministerial Meeting, December 2003. See: "The Membership Action Plan, NATO Handbook," at: http://www.nato.int/docu/handbook/2001/ hb030103.htm.

13 For more on the support of the data, see Igli Totozani, "Civilians and the Military in Defense Planning: From National Security Concept to a Force Development Plan," in Defence and Security Sector Governance. 
tivities. In case of war, five infantry brigades and one artillery reserve brigade will support this force. Following on the same purpose, the air forces will be equipped with a multi-purpose helicopter squadron in support of the rapid reaction forces and commando units. An air defense brigade and various supporting units will be added to the new structures of the air forces. As for the naval forces, they will be organized in two naval bases. A coastal surveillance battalion and various supporting units would be structured to take on the responsibilities of exercising sovereignty over territorial waters. These duties include maritime surveillance, law enforcement, and similar coastguard tasks.

In the framework of increasing the "deployability and usability" of the Albanian armed forces, the defense reforms are oriented towards making it capable to operate together with NATO structures. This has been the aim of the PfP since the beginning. In this framework, Albania has been actively supporting and participating in NATO operations and initiatives in the search for a peaceful solution to the Balkan crisis and a secure future for the region. The Albanian navy has closely cooperated with NATO and WEU missions in monitoring the UN resolutions on Yugoslavia, under the "Sharp Guard" operation. Furthermore Albania offered to the Alliance its air and naval capabilities in support of the "Safe Haven and Deny Flight" operation over Bosnia, and more recently in support of the NATO Operation Allied Force in Yugoslavia. The Albanian armed forces have participated in other national and multilateral exercises under the rubric of bilateral, regional, and NATO-PfP activities, such as Cornerstone 2001 in Albania, Seven Stars, Dynamic Response, and the SEEBRIG CAX exercise. Albania is also contributing a company to SFOR. Furthermore, Albanian soldiers have participated in operations outside of South-Eastern Europe, such as a special commando unit of thirty Albanian soldiers that was dispatched to Afghanistan for a period of six months within the framework of the NATO International Security Assistance Force, as part of the Turkish mission unit. Currently, Albanian forces are also in Mosul, Iraq, under the operational control of the $101^{\text {st }}$ U.S. Airborne Division as part of the international coalition in the war against terrorism. This participation has contributed both to the experience and the expertise of the Albanian armed forces and their readiness to be not only a consumer of security but a provider as well. ${ }^{14}$ All this is aimed at showing "reliability, the most precious asset of an ally," 15 which would improve the chances for Albania's early membership in NATO.

One of the priorities of the defense reforms is the establishment of an efficient system for human resources management, which would look after the education and training of the armed forces. A division of labor between the military and civil univer-

14 Action Plan for Membership of Republic of Albania in NATO, Albanian Ministry of Defense, (Tirana: 2001); and G. Robertson, NATO-Albania Relations, Strong and Growing Stronger, at the U.S. Embassy in Italy website at: http://www.usembassy.it/file2001_05/alia/ a1051815.htm (18 May 2001).

15 A. Copani, "The New Dimensions of Albania's Security Posture," NATO Review 44:2 (March 1996): 24-28. 
sities is carrying out these duties. The military university and the National Training Center are responsible solely for the training of military personnel in military professionalism. The additional knowledge - of a non-military nature - that is required for the complete formation of the military staff is acquired in cooperation with and through the civil educational system. The military education system will achieve new capabilities, however, after the establishment of the National Defense University in September 2004. ${ }^{16}$ Furthermore, the training of the Albanian troops is being carried out through different international programs. Thus, the Albanian military participates in the United States' International Education and Training (IMET) program, which aims to promote Albania's attempts to approach NATO standards and interoperability levels, which in turn will enable Albania to be more involved in the PfP program. Albanian military personnel participate in the training programs at the Marshall Center, which contributes to the improvement of knowledge on military affairs and to the enhancement of English skills, which are directly related to NATO's interoperability requests. ${ }^{17}$

\section{Conclusions}

A great deal has been achieved in the reformation of Albania's armed forces and their transformation into a professional and democratized army. Today Albania has an army that has updated its capabilities, increased its efficiency, and developed the necessary mechanisms for a transparent process of democratic control by the civilian government. However, Albania missed catching the second wave of NATO enlargement, and was not included among the new members of the Alliance. This reality has increased the pressure on the government to improve its performance, since achieving NATO membership takes more than military reforms.

Today, however, Albanian armed forces are not only consumers of security; they are able to provide it as well. Albanian armed forces have successfully participated in many military operations under NATO's aegis since 1996 in the Balkan region and in the war against terrorism after September 11, 2001. In the process, it has moved closer toward becoming a full member of the transatlantic community.

16 See Pandeli Majko, "Partnership Role in Defense Reform - From Prague to Istanbul" (2 December 2003), available at http://www.nato.int.docu/speech/2003/s031202c.htm.

17 See Hendrickson and Campbell, "NATO Expansion after Prague." 


\section{Bibliography}

Carnovale, Marco. "Vital and National Security Interests after the End of the Cold War." In European Security and International Institutions. New York: St. Martin's Press, 1991.

Copani, A. "The New Dimensions of Albania's Security Posture." NATO Review 44:2 (1996).

Katsirdakis, G. "Albania: A Case Study in the Practical Implementation of Partnership for Peace." NATO Review 46, no. 2 (1998): 22-26.

Nazarko, Mentor. "The Relationship between the Armed Forces and the New Institutions in Albania - A Model in the Making of Civilian and Democratic Control." In Defence and Security Sector Governance and Reform in South Eastern Europe: Insights and Perspectives . A Self-Assessment Study(Geneva: DCAF, 2003).. Geneva: DCAF, 2003. 